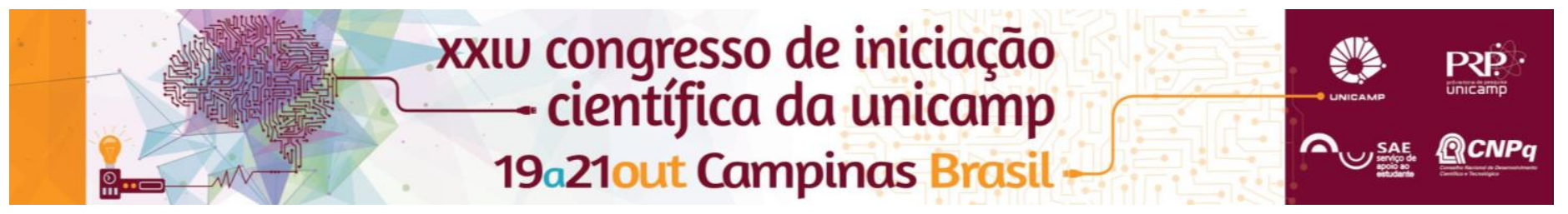

\title{
Elementos Estruturais do Imperialismo Contemporêneo
}

\author{
Rudá H. C. Miranda*
}

\begin{abstract}
Resumo
Esse painel analisa o debate entre David Harvey e Ellen Meiksins Wood acerca da configuração e dos determinantes do imperialismo capitalista contemporâneo. As principais ideias dos dois autores serão aqui sumarizadas. Primeiro temse um resumo das principais ideias de Harvey: a definição de um imperialismo capitalista a partir de uma fusão contraditória entre duas lógicas de poder antagônicas, baseado em Giovanni Arrighi, com a interação entre a lógica teritorial e a lógica capitalista de poder; sua formulação da teoria da ordenação espaço-temporal; e por fim, baseado em Rosa Luxemburgo, a acumulação por espoliação como a principal forma de acumulação pelo capital hegemônico a partir da década de 1970. Em seguida, um resumo das principais ideias de Ellen Meiksins Wood: a constituição do imperialismo capitalista pelo processo de destacamento do poder econômico e da difusão e dominância dos imperativos econômicos para a apropriação do trabalho, processo que se inicia com os EUA como novo hegemon em 1945; o papel dos Estados nacionais ao capital global; e a política militarista com a criação de um ambiente de guerra sem fim para a manutenção da ordem em âmbito global para a acumulação de capital. Por fim, as críticas trocadas entre os autores e algumas análises acerca o debate.
\end{abstract}

\section{Palavras-chave:}

Novo imperialismo, Capitalismo, Estado.

\section{Introdução}

O projeto tem como objetivo aprofundar a análise das relações imperialistas entre países em uma fase recente do capitalismo, capitalismo este internacionalizado e integrado na esfera produtiva e financeira. Para tanto o trabalho terá como base o debate entre David Harvey e Ellen Meiksins Wood, que são as principais referências no estudo e na teorização de um novo imperialismo. A partir do livro O Novo Imperialismo ${ }^{1}$ de Harvey e do livro Empire of CapitaR de Wood serão estabelecidos vínculos de complementariedade entre os autores e serão apontadas as divergências que decorrem das análises distintas, e outras referências serão utilizadas para analisar o debate e as contribuições teóricas de cada autor.

\section{Resultados e Discussão}

Ambos os autores enxergam o mesmo período histórico por meio de análises distintas. Wood, a partir de sua análise do modo de produção capitalista, enxerga uma nova forma de imperialismo propriamente capitalista a partir de 1945 e que continua até os dias atuais. Nesse período os EUA estabelecem sua hegemonia e começam a construir um capitalismo global, onde as relações imperialistas entre nações se dão por mecanismos de mercado e não mais pela dominação política ou militar direta, embora a política militar dos EUA tenha se formulado para policiar o mundo. Já Harvey enxerga um novo imperialismo a partir da década de 1970, quando os EUA reformulam a base de sua hegemonia e reorganizam o capitalismo internacional de forma a privilegiar os capitais hegemônicos por meio da acumulação por espoliação. Uma das principais divergências entre os autores está na forma de resistência política frente a esse novo imperialismo. Para Wood a luta frente ao Estado nacional permanece fundamental pois é o Estado que detém o poder político e militar, sem os quais a ordem capitalista não se sustentaria, tanto para o capital nacional como para o capital global. Para Harvey há um deslocamento da luta anti-capitalista para movimentos anti-globalização, contra instituições financeiras internacionais e grandes corporações transacionais, isso devido ao predomínio da acumulação por espoliação nessa nova ordem imperialista. A luta e a resistência, sugere Harvey, deveria partir dessa luta contra o capitalismo financeiro que promove esse tipo de acumulação, porém sem deixar de levar em conta a acumulação via reprodução ampliada do capital.

\section{Conclusões}

Do trabalho concluímos que os autores apresentam contribuições relevantes para a compreensão do capitalismo na sua fase recente. Wood destaca o papel da política militarista para a manutenção da ordem global capitalista, e Harvey destaca e explica o papel das instituições financeiras e do Estado para a circulação e acumulação do capital internacionalmente. No entanto, apesar de valiosas contribuições, há debilidades nos argumentos de ambos os autores.

O principal argumento de Wood da separação entre o poder político e o poder econômico apresenta problemas por conta do recorte nacional. Embora o capital não necessite de poderes extraeconômicos para realizar a acumulação, essa independência é muito frágil uma vez que o capital só pode se expandir para onde já se tenha estabelecido o poder político que suporte as relações de propriedade capitalistas. Já Harvey está mais preocupado em entender os mecanismos de acumulação do capitalismo financeirizado do que de fato em formular uma teoria sobre um novo impeirialismo. Sua formulação de um novo imperialismo na verdade parte da formulação do imperialismo de Rosa Luxemburgo.

${ }^{1}$ Harvey, D. O Novo Imperialismo, São Paulo, Edições Loyola, 2004.

${ }^{2}$ Wood, E. M. Empire of Capital, Londres, Verso, 2005 